\title{
IL-1 $\beta$ increases urinary corin in patients with primary proteinuric kidney diseases and in 293 cells
}

\author{
CI SUN ${ }^{1}$, LEI SHEN ${ }^{1}$, WENGANG SHA ${ }^{1}$, LING ZHOU $^{1}$, DEYU XU $^{1}$ and NINGZHENG DONG ${ }^{2}$ \\ ${ }^{1}$ Department of Nephrology; ${ }^{2}$ The Cyrus Tang Hematology Center, Jiangsu Institute of Hematology, \\ The First Affiliated Hospital of Soochow University, Suzhou, Jiangsu 215006, P.R. China
}

Received April 9, 2017; Accepted October 16, 2017

DOI: $10.3892 /$ etm.2017.5398

\begin{abstract}
Corin is a serine protease that is important for the regulation of blood pressure and water balance. Corin was initially discovered in the heart, however, it has also been detected in kidney cells, though its function in the kidneys is unclear. To further investigate the function of corin in the kidney, the present study analyzed the levels of corin in urine and blood samples collected from normal individuals and patients with primary proteinuric diseases. The associations between the levels of corin, and the cytokines interleukin- $1 \beta$ (IL-1 $\beta$ ) and tumor necrosis factor- $\alpha$ (TNF- $\alpha)$ were then assessed. The results demonstrated that corin was detectable in the urine and plasma following an enzyme-linked immunosorbent assay; the level of corin in the urine was associated with the level of urinary $\beta_{2}$-microglobulin $(P=0.01)$, which was indicative of renal tubular injury. When compared with normal individuals, the levels of urinary corin in proteinuric patients were markedly increased $(\mathrm{P}=0.02)$, and were also associated with IL-1 $\beta(\mathrm{P}=0.03)$. This correlation between corin and IL-1 $\beta$ was confirmed in vitro using 293 cells. As the IL-1 $\beta$ concentrations increased $(0,0.1,1,10 \mathrm{ng} / \mathrm{ml})$, an elevation in the level of corin was observed in the culture medium $(\mathrm{P}<0.01)$; however, the amount of corin was not markedly altered in the cell lysate $(\mathrm{P}>0.05)$. In addition, when TNF- $\alpha$ reached $10 \mathrm{ng} / \mathrm{ml}$, the level of corin in the medium increased significantly when compared with the control group ( $0 \mathrm{ng} / \mathrm{ml} ; \mathrm{P}=0.02)$, however, no significant difference in corin levels was detected in the cell lysate. The results suggest that the cytokines IL-1 $\beta$ and TNF- $\alpha$ may increase urinary corin in patients with primary proteinuric kidney diseases. Cytokines may accelerate corin shedding from the cell membrane of renal tubule epithelial cells. These
\end{abstract}

Correspondence to: Dr Lei Shen, Department of Nephrology, The First Affiliated Hospital of Soochow University, 296 Shizi Street, Suzhou, Jiangsu 215006, P.R. China

E-mail: shenlei2073@163.com

Key words: corin protein, cytokines, chronic glomerulonephritis, interleukin-1 $\beta$, tumor necrosis factor- $\alpha$ findings indicate that corin may be associated with kidney inflammation and injury.

\section{Introduction}

Corin is a type II transmembrane serine protease that is highly expressed in cardiomyocytes (1-4). The human corin gene is mapped to chromosome 4p12-13 (1) and encodes a polypeptide of 1,042 amino acids (5). In SDS-polyacrylamide gel electrophoresis and western blot analysis, human corin protein has an apparent molecular mass of $\sim 190 \mathrm{kDa}(6,7)$. The full corin protein is usually inactive and must be cleaved by proprotein convertase subtilisin/kexin type 6 (PCSK6) at Arg801-Ile802 in order to be activated, which is why a $\sim 40 \mathrm{kDa}$ band may be detected in cells expressing wild-type corin. A previous study showed that three different soluble fragments derived from corin molecules, with molecular masses of $\sim 180, \sim 160$ and $\sim 100 \mathrm{kDa}$, could be detected in the culture medium of corin-expressing human embryonic kidney (HEK) 293 cells by western blotting, and that these different sized fragments were produced by either ADAM10-mediated shedding or corin autocleavage (8).

Like other serine proteases, corin also has a catalytic domain, namely a trypsin-like protease domain, which plays a prominent role in its biological function. The corin proteolytic domain cleaves pro-atrial natriuretic peptide (pro-ANP) to form mature atrial natriuretic peptide (ANP) in the heart (6,9-11). Once activated, ANP is released into the circulation. In target organs, such as the peripheral blood vessels and kidneys, ANP binds to and activates its receptor, natriuretic peptide receptor-A (NPR-A). NPR-A increases intracellular cyclic guanosine monophosphate (cGMP) production to promote vasodilation, natriuresis and diuresis, consequently maintaining blood pressure and volume balance (12-14).

Corin plays a vital role in the control of blood pressure and volume homeostasis. In corin gene knockout mice, systolic pressure, diastolic pressure and mean arterial pressure were significantly higher than in wild-type mice $(13,15)$, and the hypertension was exacerbated by dietary salt loading $(16,17)$. Furthermore, in African Americans, polymorphisms (T555I/Q568P) in the corin gene have been shown to be associated with high blood pressure and cardiac hypertrophy (18).

As well as cardiomyocytes, corin has also been reported to be expressed in other tissues, including kidney, pregnant 
uterus, bone, skin and brain (12,19-21). In the kidney, corin was detected in epithelial cells, with segmental expression in the proximal tubule, thick ascending limb, connecting tubule, and throughout the collecting duct $(12,22)$. Fang et al reported that the levels of urinary corin were markedly reduced in chronic kidney diseases, and that the reduction correlated with disease severity (23). This suggested that corin may be shed from the cell surface of renal tubules and that urinary corin levels could be associated with the severity of kidney diseases.

Proteinuric kidney diseases are diseases associated with inflammation and immunity. Numerous studies have reported that inflammatory cytokines are increased in kidney diseases $(24,25)$. In order to determine the influence of cytokines on corin expression and the effect of this on proteinuric kidney diseases, we assessed the levels of urinary corin and plasma cytokines and the correlations between corin and cytokine levels in vivo and in vitro.

\section{Materials and methods}

Patient samples. Plasma and urine samples were collected at the First Affiliated Hospital of Soochow University from 31 patients with proteinuric kidney diseases [15 cases of chronic glomerulonephritis (CGN) and 16 cases of nephrotic syndrome (NS)] treated in the Nephrology Department, and from 21 healthy individuals who underwent a routine health check-up and reported no history of proteinuria. The present study was approved by the Ethics Committee of Soochow University (Soochow, China) and conducted in accordance with the approved guidelines. Written informed consent was obtained from all individuals recruited to the present study. At the time of sample collection, we excluded patients with infection, malignant cancer or diabetic nephropathy, and those with systemic diseases of the immune system. Characteristics of normal controls and patients are shown in Table I. Blood samples were anticoagulated with EDTA, while urine samples were collected without any anticoagulation. Blood and urine samples were centrifuged at $1,000 \mathrm{x} \mathrm{g}$ for $10 \mathrm{~min}$, then supernatant was collected and stored at $-80^{\circ} \mathrm{C}$.

Enzyme-linked immunosorbent assay (ELISA). Corin levels in plasma and urine samples were detected using an ELISA kit (R\&D Systems, Minneapolis, MN, USA). The assay was performed in 96-well plates, with the capture antibody added the night prior to the assay. During detection, plasma samples were diluted 1:2 with $1 \%$ bovine serum albumin (BSA).

Plasma cytokines [cytokines interleukin-1 $\beta$ (IL-1 $\beta$ ) and tumor necrosis factor- $\alpha$ (TNF- $\alpha)$ ] were also detected with ELISA kits (Bio Legend System, San Diego, CA). For these assays, plasma was diluted 1:2.

Urinary albumin comes from the glomeruli, and increased levels are indicative of glomerular injury. Urinary $\beta_{2}$-microglobulin ( $\left.\beta 2-\mathrm{MG}\right)$ mostly originates from the renal tubules. Albumin and $\beta 2-\mathrm{MG}$ levels in the urinary samples were assessed at the Renal Medicine Laboratory of the First Affiliated Hospital of Soochow University.

$C$-reactive protein $(C R P)$ and estimated glomerular filtration rate (eGFR). CRP in plasma was detected as part of the
Table I. Characteristics of normal controls and patients.

\begin{tabular}{lcc}
\hline Characteristics & $\begin{array}{c}\text { Control } \\
(\mathrm{n}=21)\end{array}$ & $\begin{array}{c}\text { Patients } \\
(\mathrm{n}=31)\end{array}$ \\
\hline Age (years) & $43.00 \pm 2.02$ & $49.81 \pm 2.53$ \\
Sex $(\mathrm{n})$ & & \\
Male & 12 & 18 \\
Female & 9 & 13 \\
eGFR $\left(\mathrm{ml} / \mathrm{min} / 1.73 \mathrm{~m}^{2}\right)$ & $98.12 \pm 3.69$ & $97.10 \pm 3.18$ \\
CRP $(\mathrm{mg} / \mathrm{l})$ & N/D & $1.96 \pm 0.47$ \\
Proteinuria $(\mathrm{g} / 24 \mathrm{~h})$ & N/D & $1.90 \pm 0.41$
\end{tabular}

Values are presented as the mean \pm standard error, or as the $\mathrm{n}$ numbers. Age and sex distributions were not statistically different between the controls and patients. The $24 \mathrm{~h}$ urinary proteins of normal controls were not determined (N/D). eGFR, estimated glomerular filtration rate; $\mathrm{CRP}, \mathrm{C}$-reactive protein.

routine biochemical analysis at the First Affiliated Hospital of Soochow University. eGFR was calculated by the CKD-EPI equation, which takes into account the creatinine value and patient age. The creatinine value was also obtained by biochemical analysis.

Cell culture studies. 293 cells (26) were obtained from ATCC. 293-corin cells were stably transfected with pcDNA3.1-h corin (plasmid containing full-length human corin; Invitrogen, Carlsbad, USA) (27), which was constructed by the Cyrus Tang Medical Institute of Soochow University (Soochow, China) $(9,22,28)$. In the present study, 293 corin cells were cultured in Dulbecco's modified Eagle's medium with $500 \mathrm{ng} / \mathrm{ml} \mathrm{G} 418$, at $37^{\circ} \mathrm{C}$ with $95 \%$ air and $5 \% \mathrm{CO}_{2}$. The pcDNA3.1-h corin plasmid (Invitrogen) also incorporated a C-terminal V5 tag, allowing the corin protein to be detected by western blotting using an anti-V5 antibody (Invitrogen).

In order to study the correlations between cytokine and corin levels, various concentrations $(0,0.1,1$ and $10 \mathrm{ng} / \mathrm{ml})$ of the cytokines IL- $1 \beta$, TNF- $\alpha$ and IL- 6 were added to the culture medium. The group $(0 \mathrm{ng} / \mathrm{ml})$ was added $10 \mathrm{ul}$ medium as buffer control. Subsequently, the conditioned medium was collected and the cells were lysed with lysis buffer for western blotting.

Western blot analysis. Protein samples collected from conditioned medium or cell lysates were mixed with loading buffer and heated at $98^{\circ} \mathrm{C}$ for $5 \mathrm{~min}$. After separation by SDS-polyacrylamide gel electrophoresis, the proteins were transferred to nitrocellulose membranes. After incubation with $5 \%$ milk, the membranes were probed with the aforementioned anti-V5-HRP antibody in order to label the V5 tag of recombinant corin proteins. Prior to use, the anti-V5-HRP antibody was diluted 1:5,000 in 0.05\% Tween Tris-HCl-buffered saline solution (TBST).

In the western blot analysis, corin protein in the culture medium was shown as three bands $(\sim 180, \sim 160$ and $\sim 100 \mathrm{kDa})$ on the films, which were measured by ImageJ. To normalize the values, the levels of corin in the medium were expressed 
A

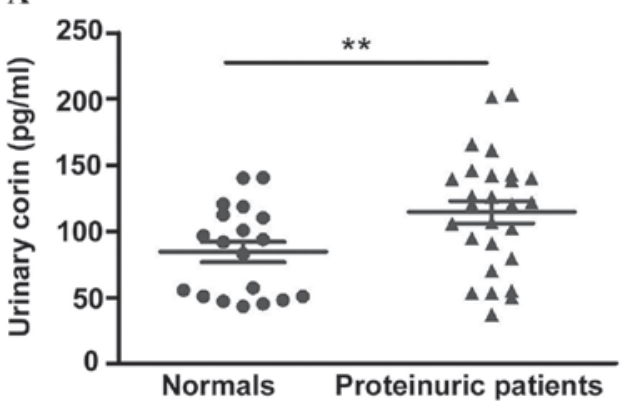

C

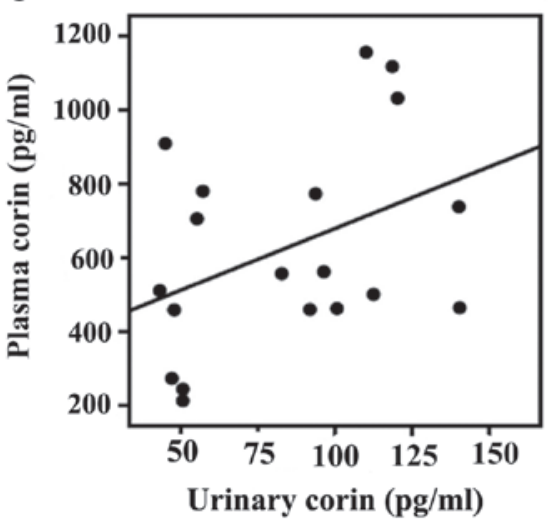

$\mathbf{E}$

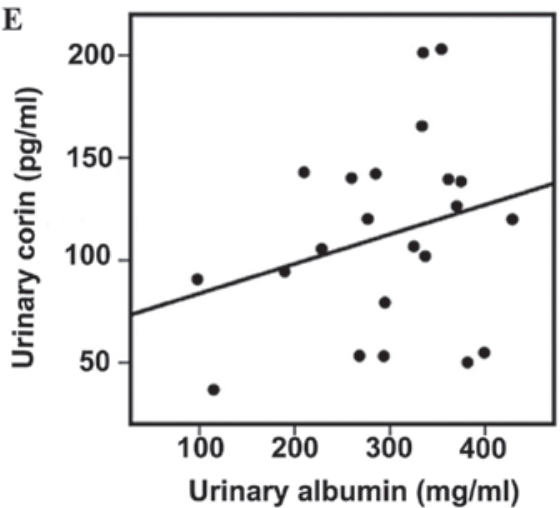

B

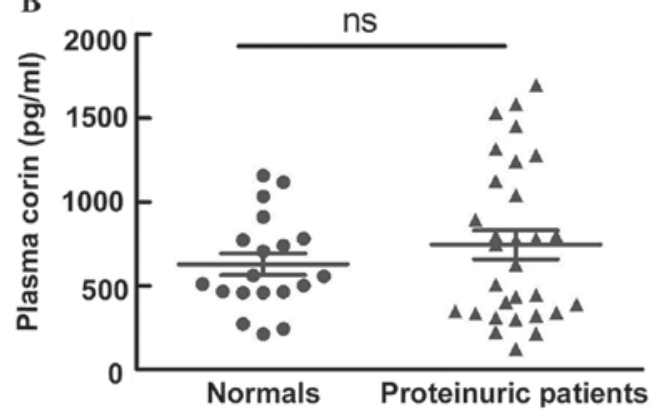

D

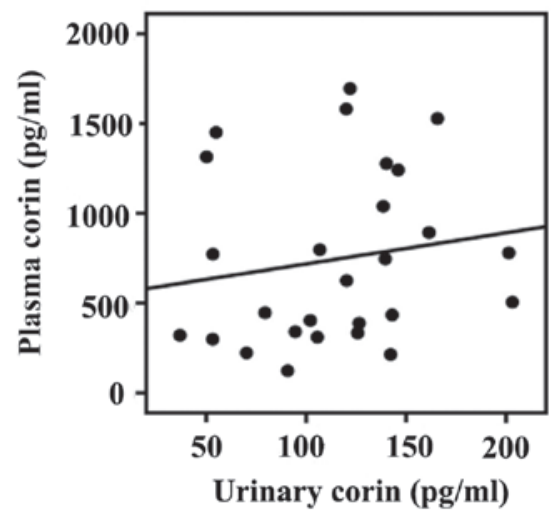

$\mathbf{F}$

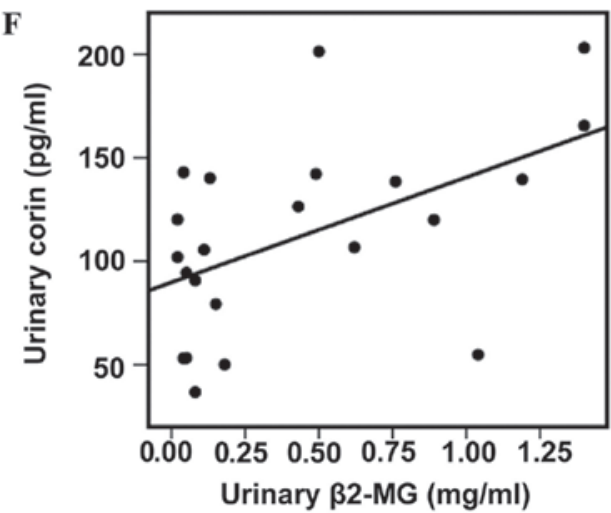

Figure 1. Corin levels in the plasma and urine. Corin could be detected in both plasma and urine samples. (A) Corin abundance in the urine of patients with proteinuric kidney diseases was higher than that in normal controls ( $\mathrm{P}=0.02$ ). (B) Corin concentration in the plasma did not differ significantly between the patient group and the normal control group $(\mathrm{P}>0.05)$. (C) There was no significant correlation between plasma and urinary corin levels in normal controls $(r=0.40, P>0.05)$. (D) There was no correlation between plasma and urinary corin levels in patients $(r=0.16, P>0.05)$. (E) No correlation was found between urinary corin and urinary albumin $(\mathrm{P}>0.05)$. (F) Urinary corin was positively correlated with urinary $\beta_{2}$-microglobulin ( $\left.\mathrm{P}=0.01\right)$. $\beta 2-\mathrm{MG}$, $\beta_{2}$-microglobulin.

as corin in medium/corin in lysate, in order to evaluate corin shedding. Corin values in the lysate were expressed as corin in lysate/GAPDH level, in order to evaluate potential differences in the rate of corin synthesis.

Statistical analysis. The statistical analysis of ELISA measurements was performed using SPSS 19 software, while western blot analysis results were analyzed using ImageJ and Prism 5 (GraphPad Software, Inc., La Jolla, CA, USA) software. All data were presented as the means \pm SE. A Pearson's correlation analysis was used to test the correlations between the levels of two proteins. For statistical comparison, a Student's t-test or one-way ANOVA were used. $\mathrm{P}<0.05$ was considered to indicate statistical significance, while $\mathrm{P}<0.01$ was considered to show marked significance.

\section{Results}

\section{Results in vivo}

Corin levels in plasma and urine. We detected the plasmatic and urinary corin levels in patients with CGN or NS and in healthy individuals. Corin could be detected in the plasma and urine (Fig. 1A and B); however, no significant correlation was found between plasma and urinary corin levels, whether in healthy individuals $(\mathrm{r}=0.40, \mathrm{P}>0.05)$ (Fig. 1C) or in patients with proteinuric kidney disease $(r=0.16, P>0.05)$ (Fig. 1D). To study the origin of urinary corin, we analyzed the association between corin level and urinary albumin (which mostly derives from glomeruli) and $\beta 2-\mathrm{MG}$ (which mostly originates from the renal tubules). The level of urinary corin was positively correlated with urinary $\beta 2-\mathrm{MG}(\mathrm{r}=0.52, \mathrm{P}=0.01)($ Fig. $1 \mathrm{~F})$, but 
A

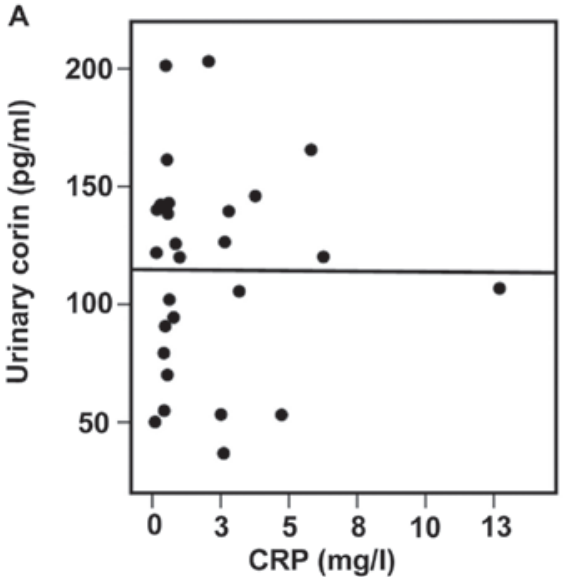

C

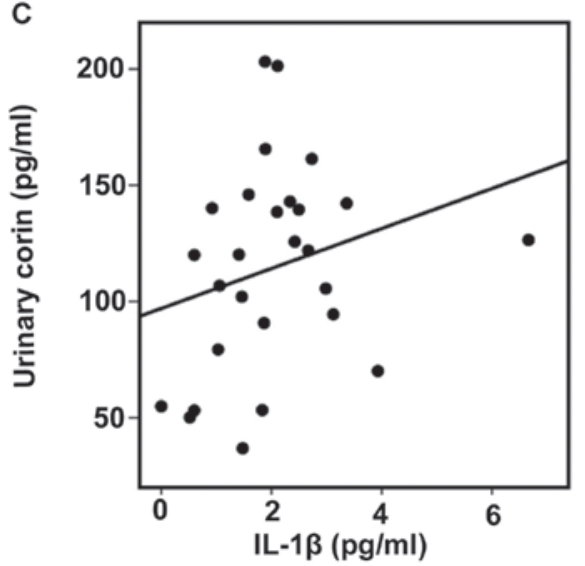

B
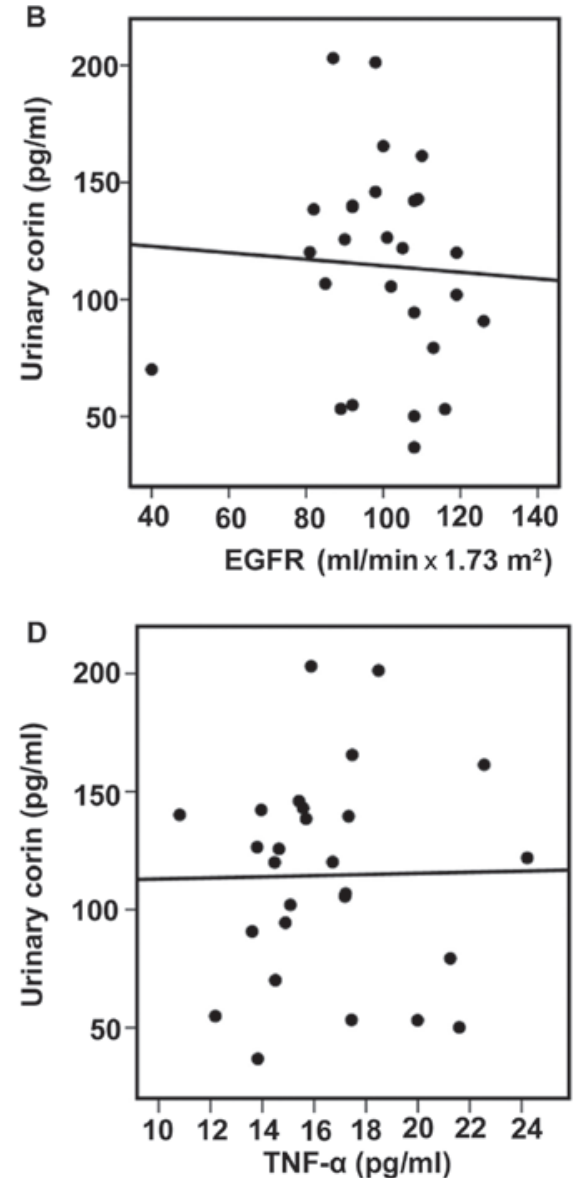

Figure 2. Correlation of urinary corin with CRP, eGFR, IL-1 $\beta$ and TNF- $\alpha$. (A) No correlation was found between urinary corin and plasma CRP levels $(\mathrm{P}>0.05)$. (B) eGFR was not correlated with urinary corin level $(\mathrm{P}>0.05)$. (C) There was a positive correlation between urinary corin and plasma IL-1 $\beta$ levels $(\mathrm{P}=0.03)$. (D) No correlation existed between urinary corin and plasma TNF- $\alpha$ levels $(\mathrm{P}>0.05)$. One-way ANOVA was used for the statistical comparison among four groups. CRP, C-reactive protein; eGFR, estimated glomerular filtration rate; IL, interleukin; TNF- $\alpha$, tumor necrosis factor- $\alpha$.

no correlation was found between urinary corin and albumin levels (Fig. 1E) (r=0.05, P>0.05).

Compared with the healthy group, corin abundance was increased in the urine of patients with proteinuric kidney disease $(84.45 \pm 7.75$ vs. $114.50 \pm 8.50 \mathrm{pg} / \mathrm{ml}$, respectively; $\mathrm{P}=0.02$ ) (Fig. 1A). However, no difference in the level of plasma corin was found between the two groups [744.90 \pm 85.29 (patients group) vs. 627.10 $\pm 64.41 \mathrm{pg} / \mathrm{ml}$ (healthy group); $\mathrm{P}>0.05$ ) (Fig. 1B).

Soluble corin and cytokine levels. To further study a possible explanation for the increased corin levels in the urine of patients with proteinuric kidney diseases compared with those of healthy controls, urinary corin levels were analyzed with respect to plasmatic CRP, eGFR, and plasma IL- $1 \beta$ and TNF- $\alpha$ levels. There were no correlations between urinary corin and CRP $(\mathrm{r}=0.10, \mathrm{P}>0.05)$ or eGFR $(\mathrm{r}=0.15$, $\mathrm{P}>0.05$ ) (Fig. 2A and B). No significant differences in IL-1 $\beta$ or TNF- $\alpha$ levels were found between healthy controls and patients [IL-1 $\beta, 1.84 \pm 0.25$ (healthy group) vs. $1.87 \pm 0.27 \mathrm{pg} / \mathrm{ml}$ (patients group), $\mathrm{P}>0.05$; TNF- $\alpha, 17.61 \pm 0.96$ (healthy group) vs. $16.19 \pm 0.65 \mathrm{pg} / \mathrm{ml}$ (patients group), $\mathrm{P}>0.05]$. However there was a positive correlation between urinary corin and plasma IL-1 $\beta$ levels ( $r=0.40 ; \mathrm{P}=0.03$ ) (Fig. $2 \mathrm{C}$ ). No correlation was found between urinary corin and plasma TNF- $\alpha$ (Fig. 2D).

\section{Results in vitro}

Corin and $I L-1 \beta$. To further study the correlation between cytokines and corin, 293-corin cells were cultured. Various concentrations $(0,0.1,1$ and $10 \mathrm{ng} / \mathrm{ml})$ of IL- $1 \beta$ were added to the culture medium. After $24 \mathrm{~h}$, conditioned medium was collected and cells were lysed, and western blot analysis was performed. As the concentration of IL-1 $\beta$ increased, the amount of corin in the conditioned medium increased significantly [expression of corin in medium/corin gross level: $0 \mathrm{ng} / \mathrm{ml}$, $0.20 \pm 0.02$ ( $\mathrm{P}<0.01$ vs. $0.1,1$ and $10 \mathrm{ng} / \mathrm{ml}) ; 0.1 \mathrm{ng} / \mathrm{ml}, 0.38 \pm 0.02$ ( $\mathrm{P}>0.05$ vs. $1 \mathrm{ng} / \mathrm{ml} ; \mathrm{P}<0.01$ vs. $10 \mathrm{ng} / \mathrm{ml}) ; 1 \mathrm{ng} / \mathrm{ml}, 0.37 \pm 0.03$ $(\mathrm{P}<0.01$ vs. $10 \mathrm{ng} / \mathrm{ml}) ; 10 \mathrm{ng} / \mathrm{ml}, 0.50 \pm 0.05$ ] (Fig. 3A), whereas the levels of corin in the lysate were not significantly different between cells treated with $0,0.1,1$ or $10 \mathrm{ng} / \mathrm{ml}$ of IL- $1 \beta$ (expression of corin in lysate/GAPDH: $1.48 \pm 0.09$ vs. $1.42 \pm 0.17$ vs. $1.74 \pm 0.20$ vs. $1.57 \pm 0.15$, respectively; all $\mathrm{P}>0.05$ ) (Fig. $3 \mathrm{~B}$ ). Subsequently, we added $1 \mathrm{ng} / \mathrm{ml}$ IL-1 $\beta$ to the cell culture medium for $12,24,36$ or $48 \mathrm{~h}$, and corin levels in the medium were shown to increase time-dependently $(0.20 \pm 0.02$ vs. $1.44 \pm 0.12$ vs. $2.91 \pm 0.30$ vs. $5.65 \pm 0.38$, respectively; $\mathrm{P}<0.01$ ) (Fig. 3C); however, the levels of corin in the lysate of these groups did not alter significantly $(\mathrm{P}>0.05)$.

Corin and TNF- $\alpha$. We cultured 293-corin cells in medium containing various concentrations of TNF- $\alpha(0,0.1,1$ 

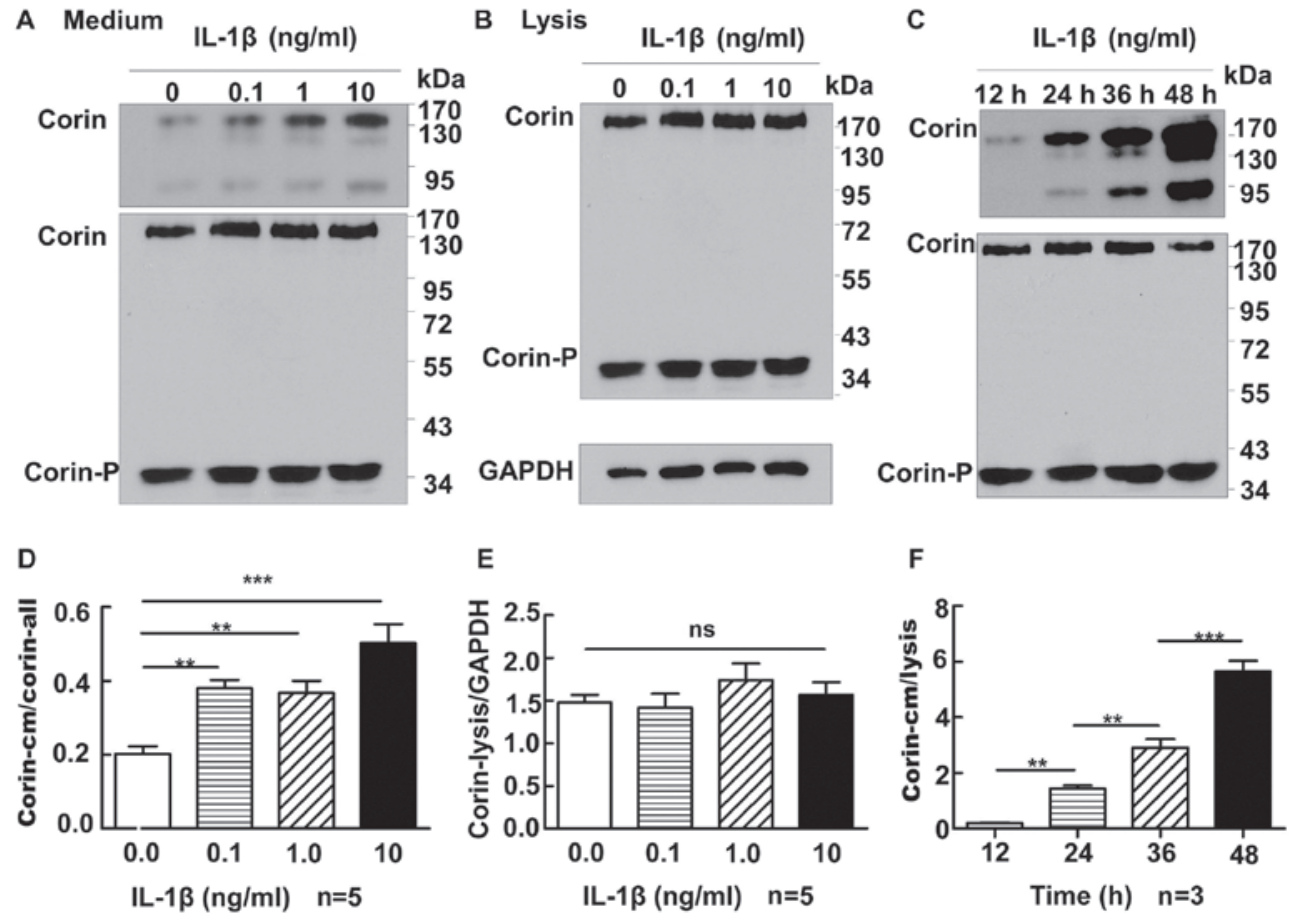

Figure 3. Correlation between IL-1 $\beta$ and corin in HEK 293 cells expressing corin. (A) In the cell culture medium, corin molecules of $\sim 180, \sim 160$ and $\sim 100 \mathrm{kDa}$ could be detected. In the cell lysate, two bands, $\sim 190 \mathrm{kDa}$ full length corin and a $\sim 40-\mathrm{kDa}$ active form, were detected. The levels of corin in the culture medium were expressed as corin in medium/corin in lysate. As IL-1 $\beta$ increased, the level of corin in the cell culture medium also increased $(\mathrm{P}<0.05)$. (B) The amount of corin in the cell lysate did not alter significantly with different concentrations of IL-1 $\beta(P>0.05)$. (C) Corin abundance in the culture medium increased with the duration of IL-1 $\beta$ treatment ( $\mathrm{P}<0.01)$. (D-F) Results of statistical analyses of $(\mathrm{A}),(\mathrm{B})$ and $(\mathrm{C})$, respectively. ${ }^{* *} \mathrm{P}<0.01$, and ${ }^{* * *} \mathrm{P}<0.0001$. One-way ANOVA was used for the statistical comparison among four groups. IL, interleukin; HEK, human embryonic kidney.

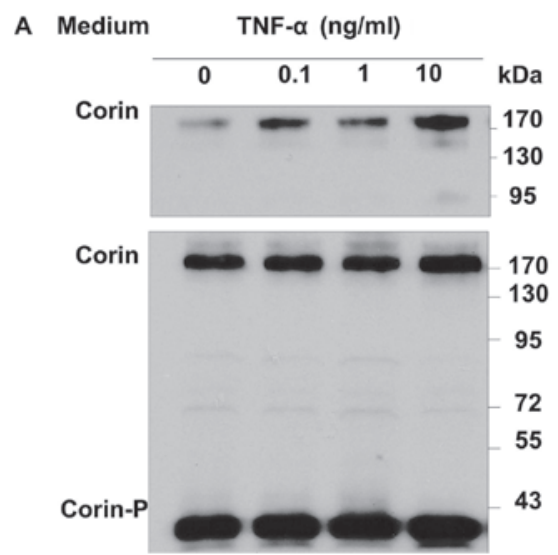

C

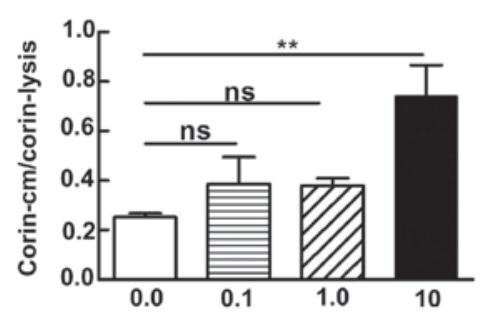

B Lysis TNF- $\alpha(n g / m l)$

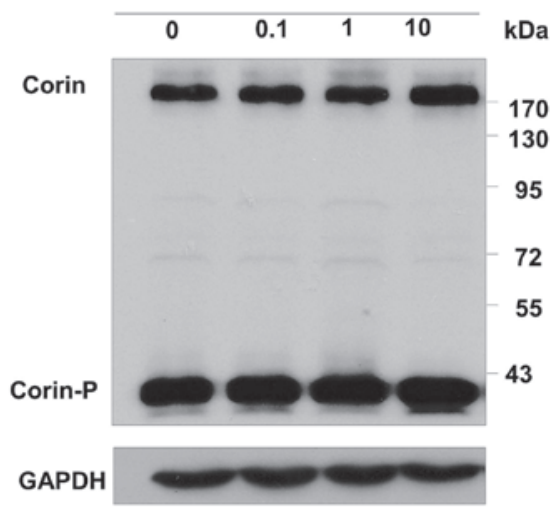

D

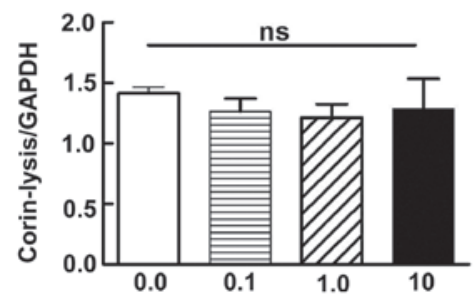

Figure 4. Correlation between TNF- $\alpha$ and corin in HEK 293 cells expressing corin. (A) Correlation between TNF- $\alpha$ and corin in cell culture medium; the level of corin increase significantly at a TNF- $\alpha$ concentration of $10 \mathrm{ng} / \mathrm{ml}$ compared with $0 \mathrm{ng} / \mathrm{ml}(\mathrm{P}=0.02)$. (B) There was no correlation between TNF- $\alpha$ concentration and corin level in the cell lysate. (C and D) Statistical analyses of (A) and (B), respectively. ${ }^{* *} \mathrm{P}<0.01$. One-way ANOVA was used for the statistical comparison among four groups. TNF- $\alpha$, tumor necrosis factor- $\alpha$; HEK, human embryonic kidney.

or $10 \mathrm{ng} / \mathrm{ml}$ ), then collected culture medium and cell lysate for analysis by western blotting. Only when TNF- $\alpha$ reached a concentration of $10 \mathrm{ng} / \mathrm{ml}$ was the level of corin in the medium increased significantly compared with the control group 


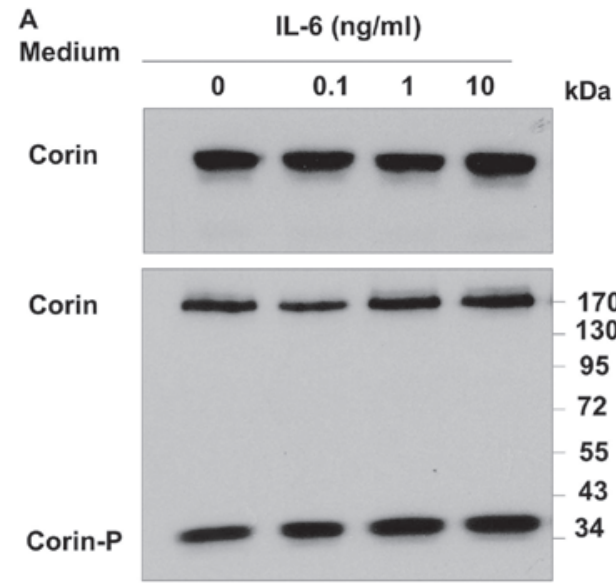

C

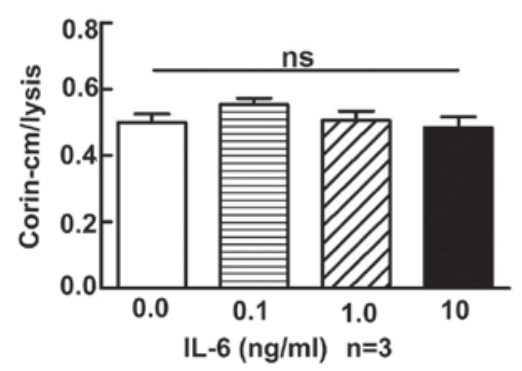

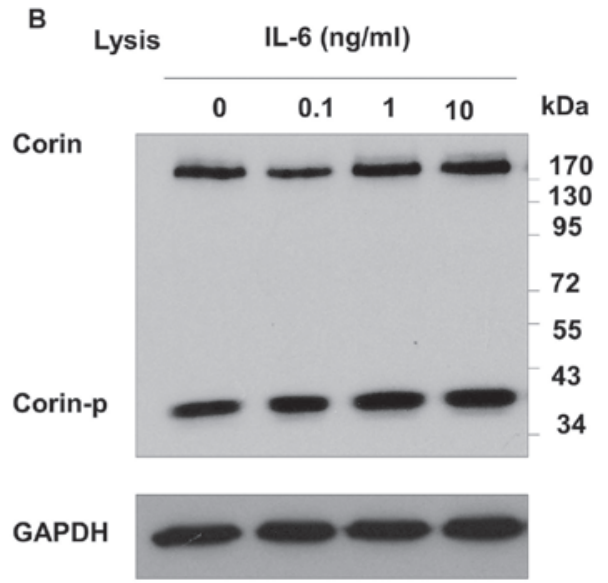

D

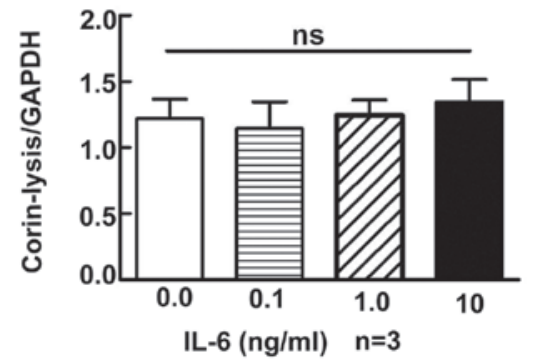

Figure 5. Correlation between IL-6 and corin in human embryonic kidney 293 cells expressing corin. (A) There was no correlation between IL-6 and corin level in the cell culture medium. (B) No correlation was found between IL-6 and corin level in the cell lysate. (C and D) Statistical analyses of (A) and (B), respectively. IL, interleukin.

$(0 \mathrm{ng} / \mathrm{ml})(\mathrm{P}=0.02)$; no significant increases were found in cells treated with 0.1 or $1 \mathrm{ng} / \mathrm{ml} \mathrm{TNF}-\alpha(\mathrm{P}>0.05)$ (Fig. 4A). The levels of corin in the lysate did not differ significantly between any of the treatment groups $(1.42 \pm 0.05$ vs. $1.27 \pm 0.16$ vs. $1.22 \pm 0.11$ vs. $1.29 \pm 0.25$, respectively; $\mathrm{P}>0.05$ ) (Fig. $4 \mathrm{~B}$ ).

Corin and $I L-6$. A similar experiment was performed to study the correlation between IL- 6 and corin levels. The concentrations of IL-6 used were $0,0.1,1$ and $10 \mathrm{ng} / \mathrm{ml}$. The amount of corin did not change markedly with increases in IL-6, in either the culture medium or the cell lysate (medium, $0.50 \pm 0.03$ vs. $0.56 \pm 0.02$ vs. $0.51 \pm 0.03$ vs. $0.48 \pm 0.03$, respectively, $\mathrm{P}>0.05$; lysate, $1.22 \pm 0.15$ vs. $1.15 \pm 0.20$ vs. $1.25 \pm 0.12$ vs. $1.35 \pm 0.17$, respectively, $\mathrm{P}>0.05$ ) (Fig. $5 \mathrm{~A}$ and $\mathrm{B}$ ).

\section{Discussion}

Corin is a serine protease that regulates blood pressure and volume balance $(13,14)$. Besides cardiomyocytes, corin has also been detected in the kidney. Corin is distributed in epithelial cells, including those of the proximal tubule, thick ascending limb, connecting tubule, and collecting duct, but not the glomerulus $(12,22)$. The specific distribution of corin in the kidney suggests that corin may play a specific role in regulating kidney physiology. Previously, we found that urinary corin in chronic kidney disease (CKD) was reduced, and that this reduction correlated with disease severity (23). However, the factors that can influence corin expression in primary proteinuric kidney diseases remain largely undetermined. Therefore, in the present study, we analyzed the relationship between corin and CRP, eGFR and three of the most common cytokines in order to investigate a possible corin expression pattern in proteinuric kidney diseases.

Although corin is a transmembrane protein (1), soluble corin is detectable by ELISA in plasma and urine samples. This suggests that corin may be shed from cell membranes into the circulation or urine. The primary source of corin in the urine is corin shedding from tubule epithelial cells; however, this is not the case for corin in the plasma, as we found that there was no correlation between urinary corin and plasmatic corin levels. As urinary albumin mostly comes from glomeruli and $\beta 2-\mathrm{MG}$ mostly originates from renal tubules, we studied their correlation with urinary corin levels to confirm the origin of the urinary corin. We found that the level of urinary corin was correlated with urinary $\beta 2-\mathrm{MG}$ but not urinary albumin, which suggested that urinary corin may originate from the renal tubules. Moreover, urinary corin levels in proteinuric patients were significantly higher than those in healthy controls, indicating that the increased level of urinary corin may be related to tubular injury in proteinuric diseases.

Proteinuric kidney diseases are usually associated with inflammation and immunity, and microinflammation can accelerate the progression of CKD $(24,25)$. To further study which factors could influence the level of corin in the urine, we analyzed the correlation between urinary corin and plasmatic CRP, eGFR and plasmatic cytokine levels (IL-1 $\beta$, TNF- $\alpha$ and IL-6). Although there were no differences in the plasmatic IL-1 $\beta$ and TNF- $\alpha$ levels between the proteinuric kidney disease group and the healthy control group, a positive correlation was identified between urinary corin and plasma IL-1 $\beta$ levels in proteinuric patients, which suggested that corin levels in the urine were sensitive to changes in IL-1 $\beta$ levels in 
the plasma. This may indicate that, in kidneys with a low-level inflammatory state, the levels of corin in the urine increase significantly. Compared with IL- $1 \beta$, only when TNF- $\alpha$ reached to $10 \mathrm{ng} / \mathrm{ml}$, the level of corin in the medium would augmented significantly. But the concentration of TNF- $\alpha$ $(10 \mathrm{ng} / \mathrm{ml})$ is higher than the plasma level. To confirm the relationship between corin and the cytokines IL-1 $\beta$, TNF- $\alpha$ and IL-6, we investigated the impact of these three cytokines on corin levels in vitro. The results revealed that IL- $\beta$ and TNF- $\alpha$ may accelerate corin shedding from the cell membrane, without having a significant effect on corin synthesis; this was demonstrated in 293-corin cells experiments, which showed that stimulation with increasing concentrations of IL-1 $\beta$ or TNF- $\alpha$ resulted in increased levels of corin in the cell culture medium, whereas corin abundance in the cell lysate samples remained unchanged. Corin responded to IL-1 $\beta$ in a time- and dose-dependent manner. However, IL-6 did not appear to have an effect on the shedding or synthesis of corin.

In summary, the levels of urinary corin in patients with proteinuric kidney diseases were higher than those in normal controls, and increased urinary corin levels were positively correlated with levels of the cytokines IL-1 $\beta$. The results indicated that certain cytokines could accelerate corin shedding from the cell membrane, but had no significant effect on corin synthesis. Further studies on corin mRNA levels and downstream signaling pathway protein (ANP, phosphodiesterase type 5 , etc) stimulated by cytokine must be done in the future. In addition, IL-1 $\beta$ and TNF- $\alpha$ often act synergistically with other cytokines, such as IFN- $\gamma$ in immunoinflammatory responses, whether IFN- $\gamma$ plays an important role in corin metabolism still need to study. Both IL-1 $\beta$ and TNF- $\alpha$ play a role in corin shedding, the binding sites on the promoter of corin are still unknown. IL-10 is an anti-inflammatory cytokine, we will go on study whether IL-10 can revert IL-1 $\beta$ and TNF- $\alpha$ induced corin production in vitro or not.

\section{Acknowledgements}

The present study was supported by a grant from the Project of Healthy in Jiangsu Province (no. H201415).

\section{References}

1. Hooper JD, Scarman AL, Clarke BE, Normyle JF and Antalis TM: Localization of the mosaic transmembrane serine protease corin to heart myocytes. Eur J Biochem 267: 6931-6937, 2000.

2. Wu Q: The serine protease corin in cardiovascular biology and disease. Front Biosci 12: 4179-4190, 2007.

3. Gladysheva IP, Robinson BR, Houng AK, Kováts T and King SM: Corin is co-expressed with pro-ANP and localized on the cardiomyocyte surface in both zymogen and catalytically active forms. J Mol Cell Cardiol 44: 131-142, 2008.

4. Chen S, Sen S, Young D, Wang W, Moravec CS and Wu Q Protease corin expression and activity in failing hearts. Am J Physiol Heart Circ Physiol 299: H1687-H1692, 2010.

5. Yan W, Sheng N, Seto M, Morser J and Wu Q: Corin, a mosaic transmembrane serine protease encoded by a novel cDNA from human heart. J Biol Chem 274: 14926-14935, 1999.

6. Yan W, Wu F, Morser J and Wu Q: Corin, a transmembrane cardiac serine protease, acts as a pro-atrial natriuretic peptide-converting enzyme. Proc Natl Acad Sci USA 97: 8525-8529, 2000.

7. Chen S, Cao P, Dong N, Peng J, Zhang C, Wang H, Zhou T, Yang J, Zhang Y, Martelli EE, et al: PCSK6-mediated corin activation is essential for normal blood pressure. Nat Med 21: 1048-1053, 2015
8. Jiang J, Wu S, Wang W, Chen S, Peng J, Zhang X and Wu Q: Ectodomain shedding and autocleavage of the cardiac membrane protease corin. J Biol Chem 286: 10066-10072, 2011.

9. Wu F and $\mathrm{Wu} \mathrm{Q}$ : Corin-mediated processing of pro-atrial natriuretic peptide in human small cell lung cancer cells. Cancer Res 63: 8318-8322, 2003.

10. Chan JC, Knudson O, Wu F, Morser J, Dole WP and Wu Q: Hypertension in mice lacking the proatrial natriuretic peptide convertase corin. Proc Natl Acad Sci USA 102: 785-790, 2005.

11. Wu F, Yan W, Pan J, Morser J and Wu Q: Processing of pro-atrial natriuretic peptide by corin in cardiac myocytes. J Biol Chem 277: 16900-16905, 2002.

12. Polzin D, Kaminski HJ, Kastner C, Wang W, Krämer S, Gambaryan S, Russwurm M, Peters H, Wu Q, Vandewalle A, et al: Decreased renal corin expression contributes to sodium retention in proteinuric kidney diseases. Kidney Int 78: 650-659, 2010.

13. Armaly Z, Assady S and Abassi Z: Corin: A new player in the regulation of salt-water balance and blood pressure. Curr Opin Nephrol Hypertens 22: 713-722, 2013.

14. Klein JD: Corin: An ANP protease that may regulate sodium reabsorption in nephrotic syndrome. Kidney Int 78: 635-637, 2010.

15. Nigrovic PA, Gray DH, Jones T, Hallgren J, Kuo FC, Chaletzky B, Gurish M, Mathis D, Benoist C and Lee DM: Genetic inversion in mast cell-deficient (Wsh) mice interrupts corin and manifests as hematopoietic and cardiac aberrancy. Am J Pathol 173: 1693-1701, 2008.

16. Wu Q, Xu-Cai YO, Chen S and Wang W: Corin: New insights into the natriuretic peptide system. Kidney Int 75: 142-146, 2009.

17. Wang W, Shen J, Cui Y, Jiang J, Chen S, Peng J and Wu Q: Impaired sodium excretion and salt-sensitive hypertension in corin-deficient mice. Kidney Int 82: 26-33, 2012.

18. Dries DL, Victor RG, Rame JE, Cooper RS, Wu X, Zhu X, Leonard D, Ho SI, Wu Q, Post W and Drazner MH: Corin gene minor allele defined by 2 missense mutations is common in blacks and associated with high blood pressure and hypertension. Circulation 112: 2403-2410, 2005.

19. Ichiki T, Huntley BK, Heublein DM, Sandberg SM, McKie PM, Martin FL, Jougasaki M and Burnett JC Jr: Corin is present in the normal human heart, kidney, and blood, with pro-B-type natriuretic peptide processing in the circulation. Clin Chem 57: 40-47, 2011.

20. Charoenpanich A, Wall ME, Tucker CJ, Andrews DM, Lalush DS and Loboa EG: Microarray analysis of human adipose-derived stem cells in three-dimensional collagen culture: Osteogenesis inhibits bone morphogenic protein and Wnt signaling pathways, and cyclic tensile strain causes upregulation of proinflammatory cytokine regulators and angiogenic factors. Tissue Eng Part A 17: 2615-2627, 2011.

21. Enshell-Seijffers D, Lindon C and Morgan BA: The serine protease Corin is a novel modifier of the Agouti pathway. Development 135: 217-225, 2008.

22. Dong L, Wang H, Dong N, Zhang C, Xue B and Wu Q: Localization of corin and atrial natriuretic peptide expression in human renal segments. Clin Sci (Lond) 130: 1655-1664, 2016.

23. Fang C, Shen L, Dong L, Liu M, Shi S, Dong N and Wu Q: Reduced urinary corin levels in patients with chronic kidney disease. Clin Sci (Lond) 124: 709-717, 2013.

24. Kalavrizioti D, Gerolymos M, Rodi M, Kalliakmani P, Provatopoulou S, Eleftheriadis T, Mouzaki A and Goumenos DS: $\mathrm{T}$ helper (Th)-cytokines in the urine of patients with primary glomerulonephritis treated with immunosuppressive drugs: Can they predict outcome? Cytokine 76: 260-269, 2015.

25. Conley SM, Abais JM, Boini KM and Li PL: Inflammasome activation in chronic glomerular diseases. Curr Drug Targets 18: 1019-1029, 2017.

26. Stepanenko AA and Dmitrenko VV: HEK293 in cell biology and cancer research: Phenotype, karyotype, tumorigenicity, and stress-induced genome-phenotype evolution. Gene 569: 182-190, 2015.

27. Dong N, Zhou T, Zhang Y, Liu M, Li H, Huang X, Liu Z, Wu Y, Fukuda K, Qin J and Wu Q: Corin mutations K317E and S472G from preeclamptic patients alter zymogen activation and cell surface targeting. J Biol Chem 289: 17909-17916, 2014.

28. Knappe S, Wu F, Masikat MR, Morser J and Wu Q: Functional analysis of the transmembrane domain and activation cleavage of human corin: Design and characterization of a soluble corin. J Biol Chem 278: 52363-52370, 2003. 